\title{
УДК 364.614.2:376-053]:316.614 \\ ДОСВІД ВИКОРИСТАННЯ АРТ-ТЕРАПЕВТИЧНОЇ МЕТОДИКИ “Я В СОЦУМІ” ЯК ЕЛЕМЕНТУ СОЦІАЛЬНО-ПЕДАГОГІЧНОЇ РОБОТИ ІЗ ДІТЬМИ-СИРОТАМИ
}

\author{
Полторак Л. Ю. \\ liubovpoltorak@gmail.com \\ https://orcid.org/0000-0002-7733-4506 \\ Чорноморський національний університет імені Петра Могили \\ Дата надходження 30.03.2020. Рекомендовано до друку 15.04.2020.
}

\begin{abstract}
Анотація. Висвітлено досвід використання розробленої автором арт-терапевтичної методики “Я в соціумі" в роботі із дітьми-сиротами та дітьми, позбавленими батьківського піклування. Описано основні моменти використання методики “Я в соціумі”, iіi функціональні можливості та очікувані результати, зокрема виявлення й усвідомлення дітьми сформованих у них патернів поведінки в соціальних групах; розуміння особистісних меж; отримання досвіду діяти новими способами; здобуття позитивного досвіду соціальної взаємодії на прикладі інших учасників групи; розвиток навичок самопізнання, емпатії, образного мислення тощо. Основну увагу дослідження зорієнтовано на висвітленні досвіду роботи за методикою в інтернатному закладі, особливості взаємодії дітей під час арт-терапевтичної роботи, їхні реакції та способи взаємодії. Описано основні труднощі, з якими зустрічаються вихованці інтернатних закладів: труднощі у висловленні своїх думок і почуттів, низький рівень рефлексії, недостатньо розвинене образне мислення, занижена самооцінка, а також підвищений рівень тривожності через події, що відбуваються на сході країни.

Ключові слова: арт-терапія, діти-сироти, діти, позбавлені батьківського піклування, школа-інтернат, соціалізація, спілкування, рефлексія
\end{abstract}

\section{Полторак Л. Ю. Черноморский национальный университет имени Петра Могилы} Использование арт-терапевтичнеской методики “Я в социуме" как элемента психолого-педагогической работы с детьми-сиротами

Анотация. Представлен опыт использования разработанной автором арт-терапевтической методики “Я в социуме" в работе с детьми-сиротами и детьми, лишенными родительской опеки. Описаны основные моменты использования методики “Я в социуме", ее функциональные возможности и ожидаемые результаты, а именно: выявление и осознание детьми сложившихся в них паттернов поведения в социальных группах; понимание личностных границ; получение опыта действовать новыми способами; получение положительного опыта социального взаимодействия на примере других участников группы; развитие навыков самопознания, эмпатии, образного мышления и т.д. Основное внимание исследования ориентировано на освещение опыта работы по методике в интернатных учреждениях, особенности взаимодействия детей во время арт-терапевтической работы, их реакции и способы взаимодействия. Описаны основные проблемы, с которыми сталкиваются воспитанники интернатных учреждений: трудности в выражении своих мыслей и чувств, низкий уровень рефлексии, недостаточно развитое образное мышление, заниженная самооценка, а также повышенный уровень тревожности из-за событий, происходящих на востоке страны.

Ключевые слова: арт-терапия, дети-сироты, дети, лишённые родительской опеки, школа-интернат, социализация, общение, рефлексия

Poltorak L., Petro Mohyla Black Sea National University

Experience of using the art-therapeutic method "I am in a society" as an element of psychological and pedagogical work with orphan children

Abstract. Introduction. Research has shown the opportunities of art-therapeutic method "I am in a society" in working with orphan children and children deprived of parental care. Purpose. The article covers the experience of using the author-developed art-therapeutic method "I Am in a Society" in working with orphans and children 
deprived of parental care. Methodology. The art-therapeutic method "I Am in a Society" was used to provide information. The method was tested in 12 settlements of Mykolaiv region and covered more than 450 teenagers, including 24 orphans. Findings. The following core points of using the author-developed art-therapeutic technique "I Am in a Society" were confirmed. Its functional capabilities and expected results: identification and awareness of the behavior patterns of children formed in them in social groups; understanding of personal boundaries; gaining experience of acting in new ways for children; obtaining social interaction positive experience on the other group members example; developing of self-knowledge, empathy, imaginative thinking and other skills. The research is primary focused on the coverage of work experience at the boarding institution, the children interaction features during art therapy work, their reactions and ways of intercommunion. The article describes the main difficulties that orphans have. These include difficulties in expressing their thoughts and feelings, low levels of reflection, poorly developed imaginative thinking, low self-esteem, and increased levels of anxiety about events in the east. Originality. The scientific novelty lies in the fact that the article describes the results of testing the author's art-therapeutic method, that was not used before. Practical value. The art-therapeutic technique "I Am in a Society" helps solve a number of psychological and cognitive problems in orphans, so the described results will be useful for psychologists, educators and social workers who work with orphans. Conclusions. The author-developed art-therapeutic technique "I Am in a Society" gave the children an opportunity to realize their current position in the team, to evaluate the effectiveness of their interaction patterns, to obtain possible ways to protect personal boundaries in communication; to be aware of their responsibility for their own place either in a group or team, to express negative emotions and to feel that they are understood. It is worth noting that for all children without exception, as they live in a boarding school, it was difficult to answer the questions. The level of self-knowledge is at a rather low level and needs further training, since it is the key to further personal, professional and social development.

Key words: art therapy, orphans, vulnerable, children deprived of parental care, boarding school, socialization, communication, reflection.

Постановка проблеми. Психологічна підтримка та соціалізація дітей-сиріт і дітей, позбавлених батьківського піклування, $\epsilon$ одним із провідних завдань закладів інтернатного типу, адже психологічний стан таких дітей значно відрізняється від дітей, які проживають вдома. У своїх дослідженнях Foster G, Makufa C, Drew R, Mashumba S, Kambeu S. зазначають, що діти-сироти зазнають додаткових стресових ситуацій, пов'язаних із змінами життя, смертю одного або обох батьків, включаючи розлуку з братами та сестрами, дитячу працю, зловживання, втрату соціальної підтримки та нестабільність у нових життєвих ситуаціях (Foster et al., 1997). Whetten K, Ostermann J, Whetten R, O'Donnell K, Thielman N. також зазначають, що вихованці інтернатних закладів, зазвичай, мають досвід потенційно травматичних подій окрім смерті батьків. Найчастіше 3-поміж таких травматичних подій трапляються насильство в сім'ї та жорстоке поводження (Whetten et al., 2011), що значно погіршує психологічний стан дітейсиріт або дітей, позбавлених батьківського піклування. Як зазначають Cluver L, Fincham DS, Seedat S, порівняно з молоддю, яка не осиротіла, діти-сироти мають вищий рівень дезадаптивного горя, посттравматичних стресових симптомів (ПТСР), депресії, суїцидальних думок і тривоги (Cluver, Fincham, \& Seedat, 2009). Водночас сучасні дослідження наголошують, що негативний життевий досвід, постійні стреси, нехтування дитиною призводять до посилення дезадаптивної та шкідливої для здоров'я поведінки, а також знижують здатність дитини до логічного мислення та сприяють емоційній деривації (McEwen, 2011; Childlineindia.org.; Musisi et al., 2007). Усе це негативно впливає на соціалізацію дитини та ії уміння вибудовувати ефективні способи поведінки у малих групах та у суспільстві в цілому. Відтак, одним із найвагоміших напрямків психолого-педагогічної роботи із дітьми-сиротами та дітьми, позбавленими батьківського піклування, $€$ надання психологічної допомоги та підвищення їхнього рівня соціалізації. На нашу думку, саме використання методів арт-терапії забезпечує ці потреби, тому основна увага нашого дослідження присвячена використанню авторської арт-терапевтичної методики “Я в соціумі”.

Аналіз останніх досліджень і публікацій. Актуальність використання методів арт-терапії у роботі з дітьми різного віку обгрунтовували у своїх працях вітчизняні та зарубіжні науковці. 
Серед них М. Кисельова, О. Копитіна, М. Костевич, А. Старовойтова, І. Лисенкова (розглядали арт-терапію як інструмент ефективного психолого-педагогічного впливу на особистість); О. Вознесенська, О. Плетка, О. Деркач, І. Дмитрієва, Л. Мова (досліджували арт-терапію як компонент навчальної діяльності та педагогічного супроводу).

Мета статті полягає у висвітленні досвіду використання авторської арт-терапевтичної методики “Я в соціумі" у роботі із дітьми-сиротами та дітьми, позбавленими батьківського піклування, з метою підвищення їхнього рівня соціалізації.

Основні результати дослідження. Арт-терапевтична методика “Я в соціумі” була розроблена автором для виявлення й усвідомлення сформованих у особистості патернів поведінки у соціальних групах з метою подальшої корекції малоефективних або неефективних способів взаємодії. Арт-терапевтична методика “Я в соціумі” може використовуватись як окрема методика або ж у поєднанні з іншими, наприклад, у тренінгових групових заняттях. Бажана кількість учасників від 5-ти до 15(20)-ти осіб. Менша кількість учасників не дає змоги простежити усі необхідні питання. Більшу кількість учасників, за необхідності, можна поділити на дві рівнозначні групи.

Арт-терапевтична методика "Я в соціумі" виконує низку вагомих функцій: діагностичну (надає можливість оцінити ситуацію і визначити відправну точку), розвивальну (створює умови для ефективного саморозвитку особистості через прийняття та пізнання себе), комунікативну (надає можливість розвивати вербальні та невербальні навички комунікаціі), інформаційну (надання інформації щодо способів соціальної взаємодії, їхніх наслідків, чинників, що впливають на соціальну поведінку, а також отримання зворотного зв'язку від інших учасників групи), соціалізуючу (допомагає особистості ефективніше реалізовувати себе у соціальних групах), корекційну (отримання нового досвіду діяти у групі або колективі та можливість перенесення цього досвіду у реальне життя).

Перед початком роботи група отримує завдання, яке доцільно сформулювати в такий спосіб: “Сьогодні ми з вами трохи помалюємо. Завдання буде озвучено лише один раз. Жодних запитань та уточнень. Ви бачите на столі ватман, фарби, пензлі. Коли я дам сигнал, кожен може підійти та обрати собі один колір, яким він буде малювати. Для кожного учасника - один колір. Ви можете малювати все, що вам захочеться до того моменту, поки я вас не зупиню або поки ви самі не вирішите, що намалювали усе, що хотіли. Важлива умова роботи - повна тиша. Тому в процесі роботи заборонено спілкуватися з іншими учасниками групи. Можете починати".

У процесі роботи соціальний педагог уважно спостерігає за роботою дітей та за необхідності фіксує необхідну інформацію. Після завершення роботи учасники розміщуються на стільцях та переходять до обговорення. 3-поміж основних питань, які порушує соціальний педагог, виділимо такі: Чому ви обрали саме цей колір? Яким чином цей колір у вас опинився: ви свідомо хотіли взяти саме його або взяли, бо не було іншого (все розібрали до вас), вам його хтось запропонував тощо? А яким чином ви дієте у житті: берете те, що хочете чи те, що дісталося? Що заважало, якщо таке мало місце, взяти той колір, який хотілося? Чим актуальний для вас образ, який ви намалювали? Про що він для вас? Хто першим розпочав малювати? Які події до цього привели? Якщо ви хотіли розпочати першим, але не зробили цього, то чому? Де розташований ваш малюнок? Скільки місця він займає на загальному аркуші? А скільки місця ви дозволяєте собі зайняти у групі? Як ви вважаєте, у якого малюнка або малюнків більш вигідне положення? Чому? Чи хотіли б ви бути на його місці? Чому? Якщо так, що для цього можна було б зробити?

Залежно від напрямку, формату роботи, обсягу відведеного часу, можуть бути використані одразу всі або лише деякі запитання. При обмеженості часу бажано обрати меншу кількість запитань, але відвести достатньо часу для їх обговорення. Варто пам'ятати, що кожна група індивідуальна і розрахувати точну кількість запитань для обговорення достатньо складно. 
Якщо методика використовується як частина іншого тренінгу або ж кількість часу вкрай обмежена, а учасників більше рекомендованої кількості, можна роздати учасникам папір та попросити їх прописати запитання та відповіді на них. Таким чином усі отримають можливість провести особистісну рефлексію.

Виходячи із функціонального потенціалу методики, можна очікувати такі результати: виявлення та усвідомлення дітьми сформованих у них патернів поведінки у соціальних групах; усвідомлення місця, яке вони дозволяють собі займати у соціальних групах, та з'ясування, наскільки така ситуація їх задовольняс; усвідомлення власної позиції: лідер чи той, кого ведуть за собою; визначення особистісних кордонів і комфортних меж у взаємодії з іншими людьми; отримання досвіду діяти новими для дітей способами; розширення навичок обстоювати свої позиції; здобуття позитивного досвіду соціальної взаємодії на прикладі інших учасників групи; об'єктивне бачення реакції інших людей на власні дії; взяття на себе відповідальності за власну позицію у соціумі; розвиток рефлексії, емпатії та образного мислення.

Творча продукція має значний діагностичний потенціал і дає змогу розкрити глибинні переживання особистості, неусвідомлені установки й індивідуальні особливості людини. Проте арт-терапевтична інтерпретація елементів малюнка не є самоціллю. Важливе значення має не лише зображення, але і його колір, особливості взаємодії символів, емоційний стан особистості тощо. Тому надзвичайно важливе значення має спостереження за процесом роботи в групі та відповіді учасників на запитання.

Розглянемо докладніше досвід використання методики у роботі із дітьми-сиротами та дітьми, позбавленими батьківського піклування. Арт-терапевтична методика "Я в соціумі" була апробована протягом 2015-2017 років у рамках проєкту “Я знаю, я можу", що впроваджувався у Миколаївській області з вересня 2015 року кафедрою соціальної роботи, управління і педагогіки Чорноморського національного університету імені Петра Могили та громадською організацією "Майстерня добра”, за підтримки Відділу преси, освіти та культури Посольства США в Україні, а також Швейцарського бюро співробітництва. Метою проєкту було підвищення рівня теоретичних знань і формування практичних навичок у напрямку особистісного саморозвитку, формування лідерської позиції, вирішення міжособистісних конфліктів, основ прав людини, активного громадянства, а також розроблення і реалізація дітьми малих соціальних проєктів. Арт-терапевтична методика “Я в соціумі” використовувалася автором у контексті роботи із лідерськими якостями та у напрямку формування навичок неконфліктної поведінки. Методика була апробована у 12-ти населених пунктах Миколаївської області та охопила більше 450-ти школярів 9-11-х класів.

Одним із закладів, де була апробована описана методика, була школа-інтернат для дітейсиріт і дітей, позбавлених батьківського піклування (з метою дотримання конфіденційності ми свідомо не зазначаємо повну назву закладу). У груповій роботі взяли участь 24 особи віком від 15-ти до 17-ти років.

Учасники були емоційно включені в роботу, брали активну участь у процесі малювання й обговорення. Учасників можна поділити на дві групи: тих, хто одразу зайняв активну позицію і швидко розпочав малювати, та тих, які довгий час стояли осторонь, не проявляючи ініціативи та спостерігаючи за роботою інших. Друга група дітей приступила до роботи, лише дочекавшись завершення роботи іншими учасниками. Відповідно перша група дітей обрали ті кольори, які хотіли, а друга група дітей обирали кольори із тих, що залишилися. Спостерігалися варіанти, коли один із учасників давав пляшечку із фарбою іншому.

Більшості дітей, які взяли участь у роботі, дуже важко було налаштуватися на рефлексію та усвідомити і назвати свої почуття, що зумовлено наявністю тяжких травматичних подій (Cluver et al., 2009; McEwen, 2011; Childlineindia.org; Musisi, 2007) умовами виховання в інтернатному закладі (Foster et al., 1997) та відсутністю такого досвіду. До того ж, сучасні 
дослідження стверджують, що 40-56\% дітей-сиріт мають проблеми емоційного розвитку та проблеми $з$ поведінкою (Kaur et al., 2018; Doku \& Minnis, 2016; Rahman, 2012; Thabet et al., 2007). У процесі обговорення було видно, що більшість дітей не замислювалися над причинами своїх дій та не звертали на них уваги, діяли за звичкою. У більшості дітей спостерігалося бажання “сподобатись”, тому вони виявляли спроби контролювати малюнки інших, з метою, щоб останні малювали щось “нормальне”, як зазначали діти. Попри те, що дітям було важко, протягом арт-терапевтичного заняття у них була можливість спробувати диференціювати свої почуття, відстежити, як вони змінюються протягом заняття.

Оцінюючи роботу, ми дійшли таких висновків. У роботі переважають яскраві кольори: червоний, рожевий, зелений тощо. Обгрунтовуючи вибір кольору, діти зазвичай зазначали: “Подобається такий колір”, “Він яскравий”, “Хотіла щось веселе”. Серед тих дітей, які стояли осторонь на початку роботи і чекали, поки перші оберуть кольори, частими були фрази: “Який залишився", “Не було того, який подобається, а цей схожий на нього”, “Просто взяв/взяла”.

Провідною темою більшості малюнків було власне ім'я, що можна пояснити бажанням авторизуватися на фоні інших та труднощами у придумуванні символічних, абстрактних образів, які можна було б зобразити на малюнку.

У багатьох дітей у роботі проявилися мовні кліше: "forever", "best", "the best" та символічні кліше такі, як “смали”. У процесі роботи було видно, що дітям важко дається образне мислення. Тому майже у всіх виникали труднощі, щоб пояснити, про що зображений малюнок. При обговоренні причин вибору тих чи інших символів діти не змогли дати чіткої відповіді, чому намалювали саме такі символи. Поширеними були відповіді: "Не знаю", "Так захотілося", "Просто намалював/намалювала".

Зображення стандартних образів можна пояснити бажанням дітей “не втратити обличчя” перед гостями закладу. Спостерігаючи за дітьми, було видно, що вони думають, що робити, що говорити для того, щоб справити “гарне" враження. Навіть один перед одним діти намагалися уникати ситуацій, в яких вони можуть проявити слабкість і “живі” емоції. Особливе невдоволення викликав у дітей малюнок одного із учнів, зроблений чорною фарбою. Проте обурення викликав лише той факт, що, на думку інших учнів, хлопець намалював “срунду”, а не щось “нормальне”. Ні в кого не викликало обурення те, що малюнок був намальований поверх зображень інших учасників заняття та порушував їхні особистісні кордони.

Ще однією із тем, які часто зустрічалися в роботі, була патріотична атрибутика та елементи, пов’язані із військовими діями. Значна частина дітей зображували прапори, герби України, танки, серця жовто-блакитного кольору тощо. У процесі обговорення було видно, що на більшість дітей значний негативний вплив справляє ситуація на Сході України. Більшість емоцій, які діти виражали на цю тему, свідчили про почуття тривоги, страху і гніву. Діти одразу жваво включалися в обговорення цієї теми та виражали свою патріотичну налаштованість.

У процесі роботи за означеною арт-терапевтичною методикою явно простежувалися проблеми у міжособистісному спілкуванні. Про це ж свідчать і сучасні наукові дослідження, у яких зазначено, що 47\% дітей-сиріт мають проблеми у соціальній поведінці та $84 \%$ - проблеми у спілкуванні з однолітками (Kaur et al., 2018). Незважаючи на те що робота була намальована учнівською групою, яка протягом тривалого часу спільно проживає на одній території та добре знає одне одного, робота не відзначається структурованістю і має скоріш хаотичний характер. Цей аспект вказує на відсутність емоційного контакту між учасниками процесу та відсутність командної роботи. Діти працюють як колектив, але не як команда. При обговоренні питань, пов'язаних із взаємодією між учасниками, діти починали висловлювати своє невдоволення діями інших, розповідати, що у побуті та навчанні у них не виходить працювати в команді та взаємодіяти без конфліктів. Труднощі виникають навіть у вирішенні побутових завдань. Так, наприклад, кожна дитина, за правилами проживання в інтернаті, несе відповідальність 
за певну роботу (чистоту на столах в їдальні, чистоту у спальні, догляд за квітами тощо). Значну частину роботи діти мають виконувати по декілька осіб, що викликає у дітей негативні емоції, оскільки у них виникають труднощі в обговоренні питань організації робочого процесу.

Як і багатьох вихованців інтернатних закладів, у цієї групи дітей чітко простежується відсутність чітких особистісних кордонів: роботи одних учасників були намальовані поверх робіт інших дітей. При цьому в процесі роботи не спостерігалися спроби "відстояти" власні кордони та якимось чином завадити такому стану речей, “захистити себе”. Це можна пояснити умовами життя дітей інтернатних закладів та користуванням спільними предметами майже у всіх сферах. 3 одного боку, це розвиває більш категоричне ставлення до тих речей, які перебувають в особистій власності, але з іншого - розмиває особистісні межі та не розвиває належним чином у дітей навичок їх захисту соціально прийнятними способами.

Отже, оцінюючи роботу цієї групи за методикою “Я в соціумі", ми дійшли висновку, що методика надала дітям можливість усвідомити своє актуальне становище у колективі, здійснити оцінку ефективності власних способів взаємодії, отримати можливі способи захисту особистісних кордонів соціально прийнятними способами; усвідомити свою відповідальність за власне місце в групі чи колективі, виразити негативні емоції та отримати відчуття, що тебе розуміють. Варто відзначити, що для всіх без винятку дітей, які проживають у школі-інтернаті, було важко давати відповіді на запитання. Рівень самопізнання на достатньо низькому рівні і потребує подальшої роботи, оскільки саме він є запорукою подальшого особистісного, професійного та соціального розвитку.

Висновки і перспективи подалыших розвідок. Таким чином, арт-терапевтична методика “Я в соціумі” є багатофункціональною і дає можливість дослідити різні аспекти прояву особистості у соціальних групах, ефективність притаманних їй способів взаємодії та впливу на інших людей. Використання методики $є$ актуальним для дітей різного віку, особливо для дітей-вихованців інтернатних типів закладів, оскільки дає змогу в цікавій і доступній формі проводити не лише діагностику, але і корекцію наявних способів поведінки у соціальних групах, розвивати навички рефлексії, образне мислення й емоційний інтелект.

У подальшому автором заплановано використання арт-терапевтичної методики “Я в соціумі” в роботі з підлітками для підвищення їхньої громадянської свідомості, а також для формування активної громадянської позиції.

\section{ЛІТЕРАТУРА}

Childlineindia.org. Childline India Foundation. Retrieved from http://www.childlineindia.org.in/ children-without-parental-care-india.htm.

Cluver, L, Fincham, DS, \& Seedat, S. (2009 Apr.). Posttraumatic stress in AIDS-orphaned children exposed to high levels of trauma: the protective role of perceived social support. $J$ Trauma Stress, 22(2), 106-12.

Doku, P. N, \& Minnis, H. (2016). Multi-informant perspective on psychological distress among Ghanaian orphans and vulnerable children within the context of HIV/AIDS. Psychological Medicine, 46(11), 2329-2336.

Foster, G., Makufa, C., Drew, R., Mashumba, S., \& Kambeu, S. (1997 Aug.). Perceptions of children and community members concerning the circumstances of orphans in rural Zimbabwe. AIDS Care, 9(4), 391-405.

Kaur, R., Vinnakota, A., Panigrahi, S., \& Manasa, R. V. (2018). A Descriptive Study on Behavioral and Emotional Problems in Orphans and Other Vulnerable Children Staying in Institutional Homes. Indian journal of psychological medicine, 40(2), 161-168. https://doi.org/10.4103/ IJPSYM.IJPSYM_316_17 
McEwen, B. S. (2011). Effects of Stress on the Developing Brain. Cerebrum, 2011. Retrieved 20.02.2020 from https://www.ncbi.nlm.nih.gov/pmc/articles/PMC3574783/.

Musisi, S., Kinyanda, E., Nakasujja, N., \& Nakigudde, J. (2007). A comparison of the behavioral and emotional disorders of primary school-going orphans and non-orphans in Uganda. African health sciences, 7(4), 202-213.

Rahman, W., Mullick, M., Pathan, M., Chowdhury, N., Shahidullah, M., Ahmed, H., Roy, S., Mazumder, A., \& Rahman, F. (2012). Prevalence of Behavioral and Emotional Disorders among the Orphans and Factors Associated with these Disorders. Bangabandhu Sheikh Mujib Medical University Journal, 5(1), 29-34. https://doi.org/10.3329/bsmmuj.v5i1.10997.

Thabet, L., \& Thabet, A. A. M. (2007). Mental Health Problems among Orphanage Children in the Gaza Strip. Adoption \& Fostering, 31(2), 54-62. https://doi.org/10.1177/030857590703100209.

Whetten, K., Ostermann, J., Whetten, R., O'Donnell, K., \& Thielman, N. (2011). More than the loss of a parent: potentially traumatic events among orphaned and abandoned children. Positive Outcomes for Orphans Research Team. Journal of traumatic stress, 24(2), 174-182.

\section{REFERENCES}

Childlineindia.org. Childline India Foundation. Retrieved from http://www.childlineindia.org.in/ children-without-parental-care-india.htm.

Cluver, L, Fincham, DS, \& Seedat, S. (2009 Apr.). Posttraumatic stress in AIDS-orphaned children exposed to high levels of trauma: the protective role of perceived social support. J Trauma Stress, 22(2), 106-12.

Doku, P. N, \& Minnis, H. (2016). Multi-informant perspective on psychological distress among Ghanaian orphans and vulnerable children within the context of HIV/AIDS. Psychological Medicine, 46(11), 2329-2336.

Foster, G., Makufa, C., Drew, R., Mashumba, S., \& Kambeu, S. (1997 Aug.). Perceptions of children and community members concerning the circumstances of orphans in rural Zimbabwe. AIDS Care, 9(4), 391-405.

Kaur, R., Vinnakota, A., Panigrahi, S., \& Manasa, R. V. (2018). A Descriptive Study on Behavioral and Emotional Problems in Orphans and Other Vulnerable Children Staying in Institutional Homes. Indian journal of psychological medicine, 40(2), 161-168. https://doi.org/10.4103/ IJPSYM.IJPSYM_316_17

McEwen, B. S. (2011). Effects of Stress on the Developing Brain. Cerebrum, 2011. Retrieved from https://www.ncbi.nlm.nih.gov/pmc/articles/PMC3574783/.

Musisi, S., Kinyanda, E., Nakasujja, N., \& Nakigudde, J. (2007). A comparison of the behavioral and emotional disorders of primary school-going orphans and non-orphans in Uganda. African health sciences, 7(4), 202-213.

Rahman, W., Mullick, M., Pathan, M., Chowdhury, N., Shahidullah, M., Ahmed, H., Roy, S., Mazumder, A., \& Rahman, F. (2012). Prevalence of Behavioral and Emotional Disorders among the Orphans and Factors Associated with these Disorders.Bangabandhu Sheikh Mujib Medical University Journal, 5(1), 29-34. https://doi.org/10.3329/bsmmuj.v5i1.10997.

Thabet, L., \& Thabet, A. A. M. (2007). Mental Health Problems among Orphanage Children in the Gaza Strip. Adoption \& Fostering, 31(2), 54-62. https://doi.org/10.1177/030857590703100209.

Whetten, K., Ostermann, J., Whetten, R., O'Donnell, K., \& Thielman, N. (2011). More than the loss of a parent: potentially traumatic events among orphaned and abandoned children. Positive Outcomes for Orphans Research Team. Journal of traumatic stress, 24(2), 174-182. 